\title{
Do Traditional Livestock Systems Fit into Contemporary Landscapes? Integrating Social Perceptions and Values on Landscape Change
}

\author{
Pablo Acebes ${ }^{1,2, *}$, Zuriñe Iglesias-González ${ }^{1}$ and Francisco J. Muñoz-Galvez ${ }^{1}$ (D) \\ 1 Terrestrial Ecology Group (TEG-UAM), Departamento de Ecología, Universidad Autónoma de Madrid, \\ 28049 Madrid, Spain; vincapervincalila@gmail.com (Z.I.-G.); fmunozgalvez@gmail.com (F.J.M.-G.) \\ 2 Centro de Investigación en Biodiversidad y Cambio Global, Universidad Autónoma de Madrid, \\ 28049 Madrid, Spain \\ * Correspondence: pablo.acebes@uam.es
}

Citation: Acebes, P.;

Iglesias-González, Z.; Muñoz-Galvez, F.J. Do Traditional Livestock Systems Fit into Contemporary Landscapes? Integrating Social Perceptions and Values on Landscape Change. Agriculture 2021, 11, 1107. https:// doi.org/10.3390/agriculture11111107

Academic Editors:

José Luis Vicente-Vicente,

Cristina Quintas-Soriano and María D. López-Rodríguez

Received: 4 October 2021

Accepted: 4 November 2021

Published: 6 November 2021

Publisher's Note: MDPI stays neutral with regard to jurisdictional claims in published maps and institutional affiliations.

Copyright: (c) 2021 by the authors. Licensee MDPI, Basel, Switzerland. This article is an open access article distributed under the terms and conditions of the Creative Commons Attribution (CC BY) license (https:// creativecommons.org/licenses/by/ $4.0 /)$.

\begin{abstract}
European traditional cultural landscapes are increasingly modified by rural abandonment and urban growth processes. Acknowledged as of High Nature Value for providing multiple ecosystem services while contributing to human well-being, the future of these social-ecological systems is uncertain. Here we aim to (1) explore dominant land use and cover (LULC) changes linked to extensive livestock farming across an urban-rural gradient defined by a large city (Madrid) over the last three decades; (2) identify and classify the main driving forces shaping these landscape trajectories and; (3) acknowledge the main landscape values for promoting landscape stewardship under participatory governance frameworks. For doing so, we combine mapping analyses (CORINE Land cover) with stakeholder perceptions and positions. Our results show a dual process of progressive abandonment of agroecosystems linked to traditional livestock farming and an ever-increasing urban growth over the last three decades as the most important driving forces. The growing urban sprawl in areas close to Madrid begins to be perceived as problematic for interviewees. The decline of extensive livestock farming in detriment of tourism, particularly evident in rural areas far from Madrid, is perceived as a threat to the cultural heritage and traditions of rural people. This decline is also perceived as a worrying increase of wildfire risk. Stakeholders stressed the need of valuing extensive livestock farming to prevent rural-urban migration, dynamizing rural economies, conserving landscapes and traditions while producing food-quality products. Interviewees advocated for science-based, stakeholder-inclusive and participatory landscape planning and co-management, leading to more context-specific, regionalized policymaking.
\end{abstract}

Keywords: cultural landscapes; drivers of change; landscape planning; landscape stewardship; mixed methods; participatory governance; rural abandonment; stakeholder inclusion; urban growth

\section{Introduction}

Urbanization is one of the fundamental characteristics of European civilization. This growing process is producing a polarization of the territory between urban and rural areas, deeply impacting landscape dynamics [1]. While urban areas are facing explosive growth [2], remote rural areas are undergoing steep land abandonment [3,4]. As a consequence, there is an increasing societal demand in some of these regions to limit the rate of landscape change and to direct it towards more desirable pathways [1]. This change is particularly concerning in European traditional cultural landscapes. These landscapes are the result of 7000 years of human-nature coevolution [5], and are characterized by harboring high biodiversity, as well as providing multiple and varied ecosystem services, thus contributing to human well-being [6]. In fact, the concept of High Nature Value Farming-HNV is linked to these social-ecological systems and arises from the need to identify those forms of agricultural and livestock production characterized by low intensity, 
low inputs and reduced environmental impact. HNV systems are further threatened by depopulation and abandonment of traditional management models [7-9]. In parallel, many of these social-ecological systems are facing urban growth, resulting in new peri-urban landscapes shaping a heterogeneous mosaic of urban, rural and natural systems [2]. In these peri-urban landscapes, the co-occurring of farming, urban growth and outdoor leisure activities remains challenging.

Within this context, landscape change has become an emerging field of research [10]. Thus, landscape researchers argue for the need of understanding land use and land cover (LULC) changes to analyze landscape trajectories $[10,11]$. Land use is defined by the human use of the territory (e.g., agriculture, forestry, residential or industrial), while land cover refers to the physical and biological surface cover of the land (e.g., arable land, forest, pasture, water or artificial structures) [12]. A fruitful approach for understanding and analyzing the causes, processes and outcomes of landscape change is the concept of 'driving forces' $[6,13]$. This concept distinguishes between 'proximate drivers' and 'underlying drivers'. Proximate drivers refer to the human activities concerning land use that result in landscape changes (e.g., land abandonment, agricultural intensification, urban development). Underlying drivers represent the cultural, political, economic, technological and ecological factors such as agricultural policies, markets, or attitudes and beliefs that trigger those human actions [6,14]. This analytical framework has proven to be valuable for preventing and reducing tensions between conflicting land uses, even for predicting future scenarios $[15,16]$. It is also useful for developing strategies to achieve more desirable futures, and designing adequate policies $[10,11]$. However, the framework of proximate and underlying drivers has not yet been applied to extensive livestock systems. Furthermore, it could be of great value in discussing how these social-ecological systems can be enhanced, given their declining trend [7-9]. This approach fits with the idea of landscape stewardship, which has not received enough attention in landscape research [10]. 'Landscape stewardship' has been defined as all 'efforts to create, nurture and enable responsibility in landowners and resource users to manage and protect land and its natural and cultural heritage' [17]. Similarly, [18] believe that land management must consider the individual and societal values of landscapes, which emphasizes responsibility, collaboration, participation and communication in the planning and management of land resources. A core concept then linked to landscape stewardship is 'landscape value', that is, the place-based preferences of people associated with different biophysical and cultural landscape characteristics and elements [14]. Particularly, the idea of 'relational value', that is, the preferences, principles, and virtues associated with relationships, both interpersonal and as articulated by policies and social norms is gaining momentum in social-ecological systems $[19,20]$. Thus, the relational value is a relatively new social-ecological framing to conceptualize how people relate to and obtain value from their relationship with nature [21].

One way of addressing such multidimensional frameworks is through transdisciplinary approaches based on natural and social sciences. These approaches have proven to be efficient in understanding landscape trajectories, identifying the driving forces and contributing to a desired landscape stewardship [10,22]. Particularly, emerging methodologies and theories such as the Research and Innovation Approach [23] or the Theory of Change [24] seek to actively involve citizens, stakeholders, scientists, and policy makers in situations considered challenging. In this regard, there is a growing scientific interest and social demand for these approaches when looking for more inclusive and participatory governance frameworks to better understand landscape/ecosystem dynamics, human-nature interactions, or land management. Through the application of participatory governance frameworks, we can understand the willingness of people to act on multiple landscape functions that they perceive as crucial for their own well-being [10,25]. Governance can be understood as the structures and processes by which social systems manage their public affairs and generate and implement collective decisions to enhance societal well-being [26].

Following this epistemological approach, we conducted a case study of traditional cultural landscapes based on extensive livestock farming recognized as HNV in mountain 
and foothill areas of Madrid region (central Spain). This region is considered one of the European hotspots of urban sprawl [11]. Here, the coexistence of traditional farming practices with the growing urbanization processes is challenging for landscape planning and sustainable policymaking. We combined qualitative and quantitative methods to: (i) explore the most relevant landscape changes through the CORINE Land Cover project in an urban-rural gradient within Sierra de Guadarrama (Madrid region), and how these changes are perceived by different social actors in the territory; (ii) identify the proximate and underlying driving forces perceived as responsible for those landscape changes; (iii) examine which landscape values linked to these social-ecological systems are recognized by stakeholders and; (iv) study which forms of land stewardship they consider important to achieve multifunctional landscapes that enable sustainable landscape planning and management, based on participatory governance. Multifunctional landscapes provide food security, livelihood opportunities, maintenance of species and ecological functions as well as fulfil cultural, aesthetic and recreational needs [27]. However, the shift in land use practices, including land abandonment, has altered these landscapes and the benefits that flow from them, particularly extensive livestock systems $[28,29]$. With this study, we seek to contribute to land use science in addressing complex multifaceted "real-world problems" $[10,30]$.

\section{Materials and Methods}

\subsection{Study Areas}

The study was conducted in two areas of central Spain with a long tradition of extensive livestock farming (Figure 1): Colmenar Viejo and Tres Cantos (hereafter CV), and Sierra del Rincón and surroundings (SR). CV corresponds to two contiguous periurban municipalities north of Madrid city located in the foothills and floodplains of the Guadarrama Mountains (mean distance from Madrid: $30 \mathrm{~km}$; mean altitude: $900 \mathrm{~m}$ above sea level (m.a.s.l.)). The major land covers are pastures, wooded grasslands, shrubs and scattered Holm oak forests (Quercus ilex), and artificial (urban) covers. Although historically rural, with strong economic dependence on livestock, the proximity of Madrid city in an increasingly well-connected landscape of transport corridors and commercial centers has transformed the area in the last 40 years. SR comprises 9 municipalities located in the Guadarrama Mountains in the northeastern region of Madrid (mean distance from Madrid, $90 \mathrm{~km}$; mean altitude, 1176 m.a.s.l.). It is a mountainous area dominated by Scots pine (Pinus sylvestris), oak forests (Quercus pyrenaica, Q. petraea), scrublands (mainly colonizing abandoned agricultural fields), and pastureland (including mesotrophic pastures developed on former agricultural fields). Currently, main land uses are extensive cattle farming and leisure activities. While CV has undergone an intense urban population growth in the last 40 years (1981: 21,159 inhabitants; 2020: 100,264 inhabitants; total area: $220 \mathrm{~km}^{2}$ ), SR has suffered a depopulation process since the 1950s (1950: 2560 inhabitants; 2020: 1069 inhabitants; total area: $\left.222 \mathrm{~km}^{2}\right)$ [31]. The Madrid region $\left(8022 \mathrm{~km}^{2}\right)$ has undergone unprecedented transformation since the end of the 1980s, characterized by rapid and dispersed growth of transport networks and urban areas, accompanied by a steady decline in productive agricultural land [32,33]. 


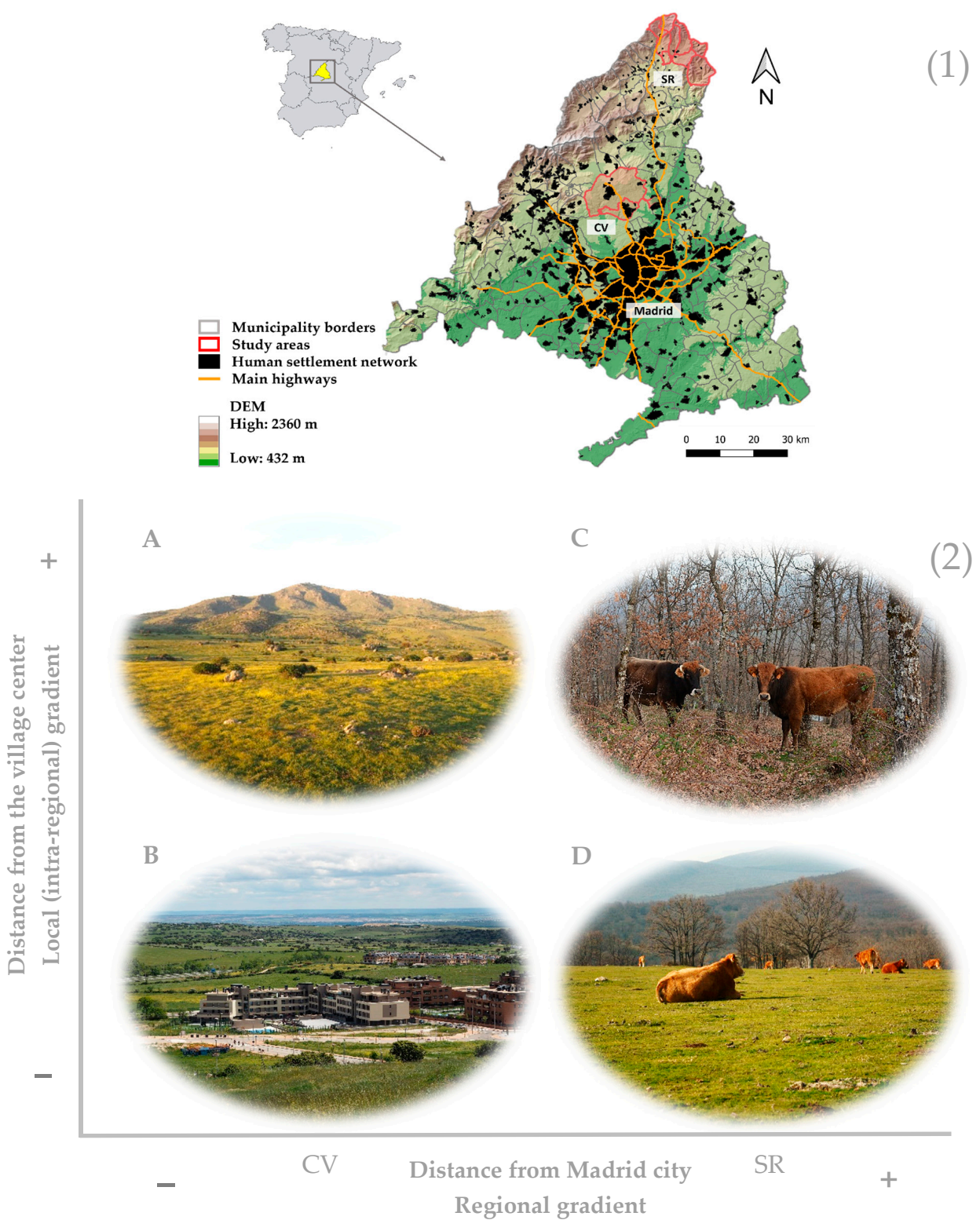

Figure 1. (1) Location of the study areas in Madrid region, Spain; (2) Pictures of the study areas within a double gradient: regional urban-rural gradient determined by Madrid city ( $x$-axis), and a local gradient of close to/far from the village center (y-axis). DEM: Digital Elevation Model; CV: municipalities of Colmenar Viejo and Tres Cantos (photos A,B); SR: municipalities included in Sierra del Rincón (photos C,D).

\subsection{Methodological Approach}

Our methodology developed a multidisciplinary approach based on mixed methods that blended qualitative and quantitative research [34], by combining approaches from social and natural sciences for the in-depth understanding of socio-ecological realities linked to the territory [10]. We sought to understand perceptions and attitudes regarding LULC changes and the associated landscape values perceived by stakeholders for the last 30 years.

To reinforce the accuracy of the data provided by the participants, we used (i) triangulation strategies between subjects (i.e., asking the same questions to all stakeholder profiles) and (ii) crossed methods (i.e., by conducting a mixed sampling than combined semi-structured interviews with questionnaires). We further combine this approach with GIS mapping analyses aiming to characterize and analyze LULC changes in the study areas. 


\subsubsection{Land Cover Data and Land Cover Changes Analyses}

We analyzed land use and land cover changes (LULC) in two areas located in the northern region of Madrid for the last 30 years, a period that has relevance to those interviewed, and of sufficient duration to identify landscape changes. The beginning of this period corresponds with the incorporation of Spain into the European Economic Union in 1986. As a result, the Common Agricultural Policy (CAP) came into force in the country. The CAP is the agricultural policy of the European Union (EU) that implements a system of subsidies for farmers and other programs (including rural development and environmental protection). The CAP impacts on agricultural landscapes, farmers and citizens across the continent and beyond [35].

To map landscape changes, we used CORINE Land Cover (CLC), a pan-European land coverage map for the entire EU territory (1:100,000 and Minimum Mapping Unit of 25 hectares) [36]. The CLC inventory was initiated in 1985 (reference year 1990). Updates, so far, have been produced in 2000, 2006, 2012, and 2018. We used 1990 and 2018 datasets to enable the identification of change over a 30 -year time period. The spatial and temporal consistency of CLC layers makes it particularly appropriate for this type of analysis. We wanted to identify and characterize (i) land cover changes linked to agricultural uses (crop production and extensive livestock grazing), (ii) land cover changes due to urban growth (artificial areas) and (iii) land cover changes triggered by agricultural abandonment and the subsequent forest and shrubland expansion (forest and seminatural areas). Based on the CLC classes we defined four categories that allowed us to distinguish between (i) urban areas; (ii) crops; (iii) pastures; pasture-shrubland areas and agroforestry systems (extensive livestock grazing); and (iv) forest and shrubland areas (without livestock grazing). The description of these new categories is as follows:

- Artificial surfaces. Areas mainly used for dwellings, leisure urban parks, institutional buildings, industrial, commercial and transport networks, but also mines, dump areas or construction sites.

- Crop production areas. Areas used for cropping, which in our study areas are mainly rain-fed cereals and small orchards.

- Livestock grazing areas. Areas mainly covered by herbaceous vegetation and sparse shrubs in some cases, and agroforestry systems with clear signs of livestock grazing, such as water points, paths, stone walls, etc.

- Forest and shrubland areas. Areas covered with (semi-)natural woody vegetation such as forests (Pinus and Quercus species) and shrublands without signs of livestock presence and/or livestock grazing.

CLC in Spain changed the methodology in 2006 for mapping the territory [37,38]. As a result, there were overestimations in some CLC categories. In particular, transitional woodlands-shrub and sclerophyllous vegetation have been identified in areas corresponding to natural grasslands and forests. This meant that comparisons between CLC1990 and CLC2018 required additional interpretation to avoid misleading comparisons [37,38]. Thus, we validated the data by comparing all land cover categories in both datasets against high resolution aerial images and cross-checking with either expert knowledge or field work. Where required, we reclassified land cover categories (see Supplementary Materials for the reclassifying process). We combined the temporal analysis (1990-2018) with the assessment of two spatial gradients: (1) an urban-rural regional gradient defined by distance to/from Madrid city, in order to study the potential influence of a large city; it is expected to be more pronounced closer to it (i.e., in CV), whereas land abandonment is expected to be more intense far away from it (i.e., in SR); (2) a local intra-regional gradient of use within each area (CV and SR), assuming that urban growth and/or the maintenance of agricultural activities will be more marked around villages than away from them, where land abandonment will be more evident.

In order to analyze spatial gradients and temporal changes together, we conducted a sampling design that mapped a portion of the territory and not the entire study areas (Figure 2). Thus, we analyzed LULC in two sets of circular plots (hereinafter plots): one 
set including the urban/village center and close surroundings ('plot around village'), and another set of plots in areas more or less away from the village center ('plot away from village center'). This design allowed us to focus on specific land covers and uses and to effectively analyze the spatial gradients. With the plots around villages, we wanted to quantify the urban growth and how this affected the very near surrounding covers/uses. The aim of the plots away from village centers was to analyze LULC changes in nonurbanized areas, but with different intensity of human use (e.g., livestock grazing, forestry or abandoned/natural). We randomly placed plots away from village center, avoiding pine plantations in the case of SR (if possible). These covers planted in the 1960s, only had marginal forestry use and could mask some changes. The size $(1 \mathrm{~km}$ radius $)$ and number of plots $(n=9)$ away from village center were equal in both areas (CV and SR), as well as the size and number of plots around village center in SR, which coincided with the number of villages there $(n=9)$. In $\mathrm{CV}$, we placed 2 plots of $3 \mathrm{~km}$ radius around the two urban centers (Colmenar Viejo and Tres Cantos). This size was modified and fitted to their urban size (Figure 2). Mean urban area in 2018 was of $0.054 \mathrm{~km}^{2}$ in SR vs. $9.22 \mathrm{~km}^{2}$ in CV. Due to the small size of villages in SR, that were below the Minimum Mapping Unit of CLC, we mapped these villages from aerial images from 1991 and 2018 to analyze possible changes in urban area between periods.

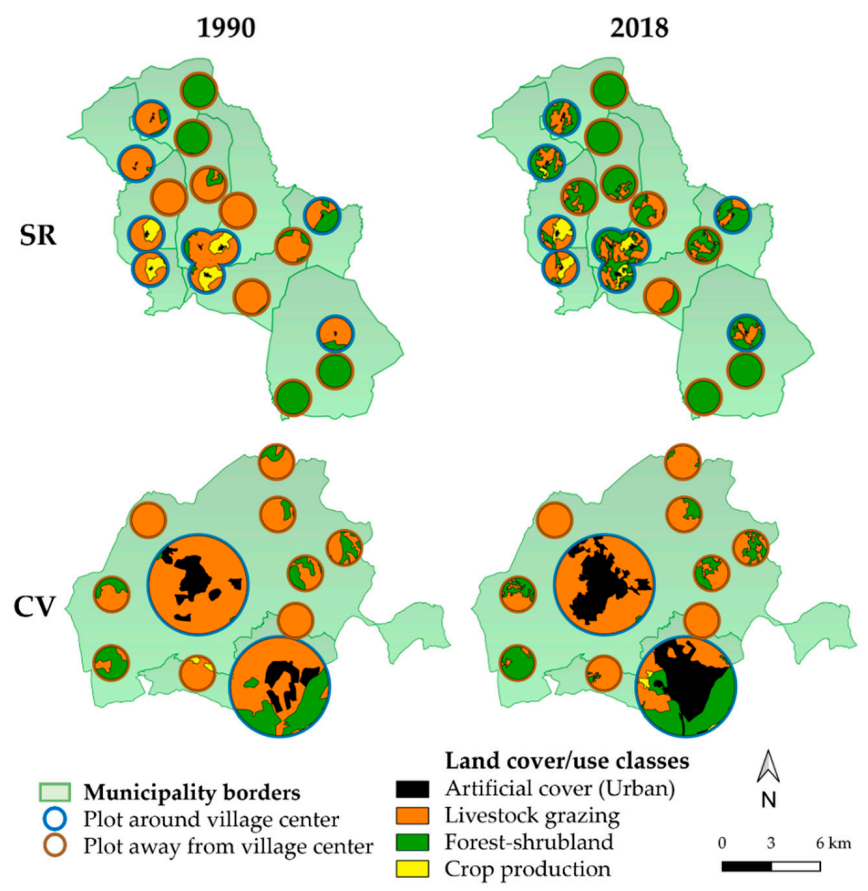

Figure 2. Mapping design and analysis based on two sets of plots placed on a portion of the territory. The map shows the land cover/use classes reclassified from CORINE Land Cover datasets of 1990 and 2018 for both study areas (CV and SR).

\subsubsection{Key Informant Selection}

We first designed a 'key informant sampling', that is, a sampling method based on the identification of informants with recognized knowledge and/or a relevant position in the territory. This approach was combined with a 'snowball sampling', i.e., asking each interviewee for more potential informants. We chose key informants holding different linkages with the territory who may show divergent positions and classified them into three groups (Table 1). 
Table 1. Number $(\mathrm{N})$ and type of stakeholders interviewed arranged in three social groups and by study area. Code: identification of stakeholders for recognizing the quotes in the text. All officers work for the local/regional government on environmental projects. CV: Colmenar Viejo and Tres Cantos; SR: Sierra del Rincón.

\begin{tabular}{|c|c|c|c|c|c|c|c|c|}
\hline \multirow{2}{*}{ Social Group } & \multirow{2}{*}{ Stakeholders } & \multicolumn{2}{|c|}{ Inter-Territorial } & \multicolumn{2}{|c|}{$\mathrm{CV}$} & \multicolumn{2}{|c|}{ SR } & \multirow[b]{2}{*}{ Ntotal } \\
\hline & & $\mathbf{N}$ & Code & $\mathbf{N}$ & Code & $\mathbf{N}$ & Code & \\
\hline \multirow[t]{2}{*}{ Ecologist } & Academia & 8 & $\mathrm{AC}$ & & & & & 8 \\
\hline & Environmental NGO & 2 & EN & 1 & Encv & & & 3 \\
\hline \multirow[t]{4}{*}{ Rural } & Livestock farmer association & 1 & LFA & & & & & 1 \\
\hline & Farmer/shepherd & & & 5 & $\mathrm{FcV}$ & 5 & Fsr & 10 \\
\hline & Beekeeper & & & 1 & $\mathrm{BK} c \mathrm{v}$ & 1 & $\mathrm{BKsr}$ & 2 \\
\hline & Hunter & & & 1 & $\mathrm{HTcv}$ & 1 & HTsr & 2 \\
\hline \multirow[t]{4}{*}{ Officer } & Administration & & & 2 & Adcv & 2 & Adsr & 4 \\
\hline & Environmental technician & & & 1 & Eocv & 2 & Eosr & 3 \\
\hline & Forest ranger & & & 3 & FRcv & 4 & FRsr & 7 \\
\hline & Veterinarian & & & 2 & VTcv & 1 & VTsr & 3 \\
\hline
\end{tabular}

\subsubsection{Interview Design and Analyses}

We conducted 43 semi-structured interviews between February and July 2020; nearly all were done via videoconference (e.g., Skype, Zoom) due to COVID-19 confinement, and lasted 70-90 min. Before starting the interview, we explained in detail the purpose of the research project, the expected duration, the further use of the data and the expected ways of dissemination. We requested an informed consent.

We proposed the following conversation topics: (1) LULC changes in the territory; (2) conflicts and synergies between land uses; (3) drivers of change of LULC; (4) role, challenges and threats of extensive livestock farming; (5) proposals to promote sustainable rural development and nature conservation, and; (6) public policies and societal demands. We designed a pilot interview with initial questions to check for the length, language suitability and potential sources of bias. The pilot interview questions were tested with four interviewees, and slightly adapted to ensure that interviewees clearly understood all the questions [39]. These pilot interviews were also included in the subsequent analysis. We voice recorded interviews and we transcribed them verbatim with the InqScribe 2.2.4 software for further analysis. Interview transcriptions were analyzed through a directed content analysis [40]. This type of analysis consists of sorting the responses (by researchers) into predetermined categories at the beginning of the analysis, which are modified and enriched as the transcript progresses. Thus, we first created coding categories based on the research questions. These categories were then modified and continuously reviewed based on the responses of the interviewees throughout the interview coding process. We used Atlas.ti 7.5.4 software (ATLAS.ti Scientific Software Development GmbH, Berlin, Germany) for this analysis.

Furthermore, we classified the final coding categories (i.e., once the direct content analysis was finished) according to the framework on LULC drivers of change given by [10]: proximate drivers (human actions that have a direct effect on landscape changes), and underlying drivers (the cultural, political, economic, technological and ecological factors that trigger those human actions) [6]. These driving forces were not given to the informants, but they were extracted from their discourses. We further classified underlying drivers based on the expertise of the researchers according to their scale of impact (local, regional, national, international). We also identified the landscape values and planning actions from interviewee discourses for an inclusive stewardship. The added value of this approach is the specific analysis of extensive livestock farming through the prism of the proximate and underlying drivers, the landscape values and landscape stewardship perceived or desired by different social actors of the territory. 


\subsubsection{Questionnaire Design and Analyses}

We performed 41 questionnaires at the end of interviews to contrast and complete informant perceptions regarding shrub expansion and socio-political opinions about $\mathrm{CAP}$, thus deepening on issues of greater interest or that can be better characterized with a quantitative approach. The questionnaire was made up of open and closed-list questions (pre-established options), and a Likert scale, which assessed the level of agreement and disagreement regarding a series of statements based on scientific literature and media. The data were transferred to a spreadsheet from which descriptive statistics were extracted and presented graphically using the R 3.5.2 software (R Foundation for Statistical Computing, Vienna, Austria) with ggplot2 package [41].

\section{Results}

3.1. Land Cover Changes across Urban-Rural Gradient: Mapping Analyses vs. Stakeholder Perceptions

Mapping analyses showed LC changes in both spatial gradients over the study period (Table 2). First, forest-shrubland and urban areas have increased over the last 30 years (37.6\% and $54.2 \%$, respectively). In contrast, livestock grazing and crop production areas have decreased (32.4\% and 18.5\%, respectively). Second, SR had more forest-shrubland areas $(60.1 \%)$ than CV (21.1\%). In SR these covers have 2-fold increase in 30 years. This shift has occurred mostly at the expense of decreasing pastures and other covers for livestock grazing. Third, in CV pastures and agroforestry systems were the predominant cover $(53.4 \%)$. These covers have decreased especially in the near surroundings of villages $(34.9 \%)$ due to urban growth, which has increased 2.2-fold in the last 30 years. Forth, forest-shrubland areas have increased less in areas far away from villages than in areas around villages, which is contradictory to the expected local gradient of use (close to/far from the village). Being territories of similar area (CV: $220 \mathrm{~km}^{2}$; SR: $\left.222 \mathrm{~km}^{2}\right)$, the urban cover in CV was 24.9 larger than in SR in 1990. In 2018, urban cover was already 43.5 larger in CV.

Table 2. Land uses and covers in the study areas based on Corine Land Cover Project (CLC 1990 and 2018), distinguishing between areas 'around village center' and 'away from village'. Two gradients are illustrated: urban growth and naturalness/abandonment. $\Delta$ is the rate of change (\%) of each land cover between the two periods. CLC 1990 and 2018 are measured in km². CV: Colmenar Viejo and Tres Cantos municipalities; SR: Sierra del Rincón. * Urban cover in SR was estimated from high-resolution aerial imagery for the same dates.

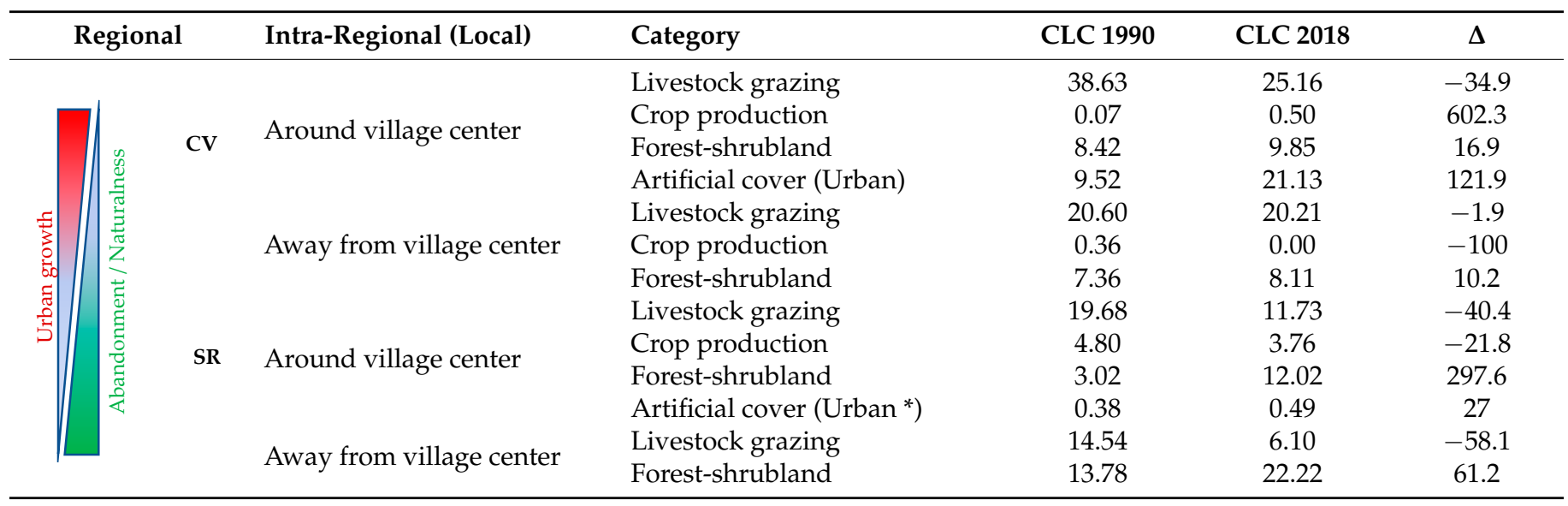

Regarding stakeholder perceptions, all social groups in SR perceived a more intense increase of shrub expansion and afforestation in detriment of pastures. Stakeholders further perceived a landscape homogenization as a result of land abandonment $(\mathrm{N}=22 ; 53 \%)$. "The real abrupt change has occurred in SR; there are places where sheep even goat cannot get into. It is becoming a forest landscape" (Fsr). Some officers and environmental NGOs (N =3;7\%) further indicated that shrub expansion was less intense in CV due to livestock farming 
that remained the most widespread land use in the territory out of the urban growth areas. All social groups from CV and inter-territories highlighted the intense urban growth and the increase of transport infrastructures (highway, railway) in CV due to the proximity of Madrid city $(\mathrm{N}=17 ; 41 \%)$. "CV has suffered a vertiginous urban growth at expense of rural land" (AC).

\subsection{Proximate Drivers of Land Cover Changes}

Almost all interviewees identified land use changes in recent decades as responsible for the perceived and mapped land cover changes $(\mathrm{N}=37 ; 90 \%)$. The main perceived change was the progressive decrease of the primary sector (livestock farming, crop production and forestry) in favor of economic activities linked to secondary and tertiary sectors $(\mathrm{N}=15$; $36 \%$; Figure 3). According to interviewee comments, a noticeable increase in construction activities for housing, transport corridors, services and light industry has happened in $\mathrm{CV}$ in detriment of pastures over the last 30 years (Figure 3): "this is pure brick, here most of those who left the agriculture have become bricklayers, plumbers, electricians ... " (FRcv). In $\mathrm{SR}$, recreational activities have increased, although this growth has not led to a significant urban expansion, but to the rebuilding of old constructions for tourism purposes. This shift resulted in new forms of employment for local people (Figure 3): "So, there has been a clear tertiarization of the economy in SR: everyone has set up a bar, a restaurant, a rural house, or a campsite.... or they have dedicated to things related to tourism" (VTsr). Interviewees further perceived an increase of sport activities (hiking, biking, etc.) in natural areas (Figure 3). Several stakeholders acknowledged a decline of crop production $(\mathrm{N}=13 ; 31 \%)$. This decline was characterized by the abandonment of private orchards and cereal crops (oat, rye wheat and barley) and their conversion into pastures for livestock grazing. Several stakeholders further expressed a reduction of forestry in SR ( $N=10 ; 24 \%)$, especially wood harvesting for local consumption.

Livestock farming was considered by interviewees as the main land use in the territory and the activity that has contributed most to shape these landscapes. The changes of livestock farming was explained as the progressive shift in terms of livestock type and management modes since the second half of the 20th century (Figure 3); interviewees belonging to all social groups mentioned (i) the decline of small ruminants (sheep and goats), which where dominant until the 1970s, in favor of cattle ( $\mathrm{N}=28 ; 68 \%)$ : "We have shifted from seasonal shepherds holding small livestock to free-range cattle all year round" (EN); (ii) a shift from dairy (intensive) cattle to beef (extensive) cattle farming $(\mathrm{N}=13 ; 31 \%)$ in 1980s; and (iii) the shift towards larger farms managed by fewer farmers: "There used to be more farms, and with more farmers, each one took his cattle to a specific area so that the whole territory was grazed" (ADsr). Ecologists, officers and rural actors considered that these changes were responsible for the landscape changes $(\mathrm{N}=23 ; 56 \%)$; contrary to sheep and goats, cattle graze in a limited proportion of the territory usually around villages and receive supplementary fodder (Figure 3). Likewise, stakeholders stated the progressive abandonment of fields (grazing areas) further away from villages and in those areas difficult to access for farmers. Stakeholders also mentioned the loss of traditional management practices such as transhumance, the underuse of drove roads and the complementary use of crops and pastures: "A cereal-legume and fallow crop rotation was done and where the sheep came in to eat the stubble" (Fsr). 


\section{PROXIMATE DRIVERS}

\section{Decrease of primary sector}

- Agriculture (crop) decline

- Decrease in forestry

- Changes in livestock systems
- Shift from small ruminants to cattle

- Replacement of intensive dairy farms

by extensive beef cattle

- Reduction of farmers and increase of farm size

- Reduction in grazed resources
Increase of secondary and tertiary sectors

- Urban growth

- Expansion of transport infrastructure

- Tourism development

- Increase of leisure activities

\begin{tabular}{|c|c|c|c|c|c|}
\hline 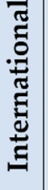 & $\begin{array}{l}\text { Competition } \\
\text { with } \\
\text { international } \\
\text { market } \\
(\mathrm{N}=15 ; 35 \%)\end{array}$ & $\begin{array}{l}\text { Social disapproval } \\
\text { of meat } \\
\text { consumption } \\
(\mathrm{N}=8 ; 19 \%)\end{array}$ & $\begin{array}{l}\text { Common } \\
\text { Agricultural } \\
\text { Policy } \\
(\mathrm{N}=32 ; 74 \%)\end{array}$ & $\begin{array}{l}\text { Promotion of } \\
\text { farm } \\
\text { technification } \\
(\mathrm{N}=5 ; 12 \%)\end{array}$ & $\begin{array}{l}\text { Climate } \\
\text { change } \\
(\mathrm{N}=8 ; 19 \%)\end{array}$ \\
\hline 胥 & $\begin{array}{l}\text { Price of livestock } \\
\text { products } \\
(\mathrm{N}=12 ; 28 \%)\end{array}$ & $\begin{array}{l}\text { Little } \\
\text { acknowledgement } \\
\text { of the ecosystem } \\
\text { services provided } \\
\text { by livestock } \\
(\mathrm{N}=16 ; 37 \%)\end{array}$ & $\begin{array}{l}\text { Promotion of } \\
\text { tertiary sector } \\
(\mathrm{N}=3 ; 7 \%)\end{array}$ & & \\
\hline 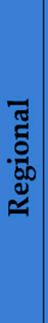 & $\begin{array}{l}\text { Low } \\
\text { profitability of } \\
\text { small farms } \\
\text { ( } \mathrm{N}=8 ; 19 \%) \\
\text { Tertiarisation } \\
\text { of economy } \\
\text { ( } \mathrm{N}=15 ; 35 \%)\end{array}$ & $\begin{array}{l}\text { Conflicts between } \\
\text { urban and rural } \\
\text { interests } \\
(\mathrm{N}=5 ; 12 \%)\end{array}$ & $\begin{array}{l}\text { Lack of livestock- } \\
\text { friendly legislation } \\
(\mathrm{N}=11 ; 26 \%) \\
\text { Poor adminstration } \\
\text { efficiency }(\mathrm{N}=10 ; 23 \%) \\
\text { Low demographic } \\
\text { weight of rural } \\
\text { population }(\mathrm{N}=2 ; 5 \%)\end{array}$ & $\begin{array}{l}\text { Decline in } \\
\text { livestock } \\
\text { infrastructure } \\
(\mathrm{N}=5 ; 12 \%)\end{array}$ & $\begin{array}{l}\text { Land access } \\
(\mathrm{N}=11 ; 26 \%)\end{array}$ \\
\hline శ్ & $\begin{array}{l}\text { Comercialisation } \\
\text { channels } \\
(\mathrm{N}=4 ; 9 \%)\end{array}$ & $\begin{array}{l}\text { Increase in part-time } \\
\text { cattle-raisers }(\mathrm{N}=14 ; 33 \%) \\
\text { Time-consuming } \\
\text { activity }(\mathrm{N}=6 ; 14 \%) \\
\text { Low generational } \\
\text { turnover }(\mathrm{N}=20 ; 47 \%) \\
\text { Land access }(\mathrm{N}=2 ; 5 \%)\end{array}$ & $\begin{array}{l}\text { Lack of support } \\
\text { for traditional } \\
\text { activities } \\
(\mathrm{N}=11 ; 26 \%)\end{array}$ & $\begin{array}{l}\text { Decline in } \\
\text { livestock } \\
\text { infrastructure } \\
(\mathrm{N}=5 ; 12 \%)\end{array}$ & $\begin{array}{l}\text { Wild animal } \\
\text { attacks } \\
(\mathrm{N}=5 ; 12 \%) \\
\\
\text { Disease } \\
\text { transmission by } \\
\text { wild ungulates } \\
(\mathrm{N}=13 ; 30 \%)\end{array}$ \\
\hline & Economic & Social/Cultural & Political/Institutional & Technological & Natural/Spat \\
\hline
\end{tabular}

UNDERLYING DRIVERS

Figure 3. Proximate and underlying drivers of land use and land cover changes identified by stakeholders focusing on livestock-related factors in two study areas of Madrid region. The proximate drivers (top) identified by the stakeholders are shown according to the main topics. The underlying drivers (bottom) are adaptations of the topics mentioned by the interviewees, nested according to their scale of impact, and categorized by the typology suggested in [6]. The most frequently cited underlying drivers are highlighted in bold. Gaps of information are due to lack of mention by the interviewees.

\subsection{Underlying Drivers of Land Cover Changes}

Stakeholders identified several underlying drivers acting at different scales, from local to international. These drivers were related to economic, socio-cultural, political, technological and natural issues as responsible for LULC changes (Figure 3). Moreover, stakeholders related proximate drivers such as the aggregation of livestock on fewer farmers and their part-time dedication to underlying drivers such as low profitability of small farms, particularly those of sheep and goats; since beef cattle management is less time-consuming, farmers may have a second job. "The main problem faced by farmers is 
the low farm profitability and low meat prices and other livestock-derived products" (Fsr). This low profitability of farms together with very demanding work was explained as being responsible for the low generational turnover. In addition, the difficulty of land access for the incorporation of new farmers was emphasized as a major drawback (Figure 3); almost all farmers in the territory inherited land and/or livestock from their families.

Rural abandonment in SR was perceived as a lack of attention from administration to the rural claims and needs, where a feeling of abandonment was shared by local people $(\mathrm{N}=3 ; 7 \%)$ : "a shift in the weight of farmers has occurred, who were a majority in the past, but currently are a minority from demographic and economic points of view" (AC). Accordingly, several interviewees perceived that livestock farming was not a priority for administrations ( $\mathrm{N}=11 ; 26 \%$ ), and that it was scarcely acknowledged for providing ecosystem services (Figure 3).

CAP subsidies were broadly perceived as an essential economic support of livestock farms: "If we were to remove the CAP, possibly $50-60 \%$ of livestock farming in Spain would disappear, since extensive livestock farming would not be competitive" (VTcv). In contrast, other interviewees argued that CAP produced an overdependence of livestock farmers on subsidies, thus favoring farming intensification. Interviewees generally considered that CAP 2023-2027 will bring benefits to extensive livestock farming (Figure 4).

CAP direct payments help maintain traditional extensive livestock farming

There is an adequate CAP support for the maintenance of indigenous livestock breeds

CAP agri-environmental measures related to livestock farming are efficient in promoting local biodiversity

I hope that the new CAP 2023-2027 will bring improvements to support extensive livestock farming

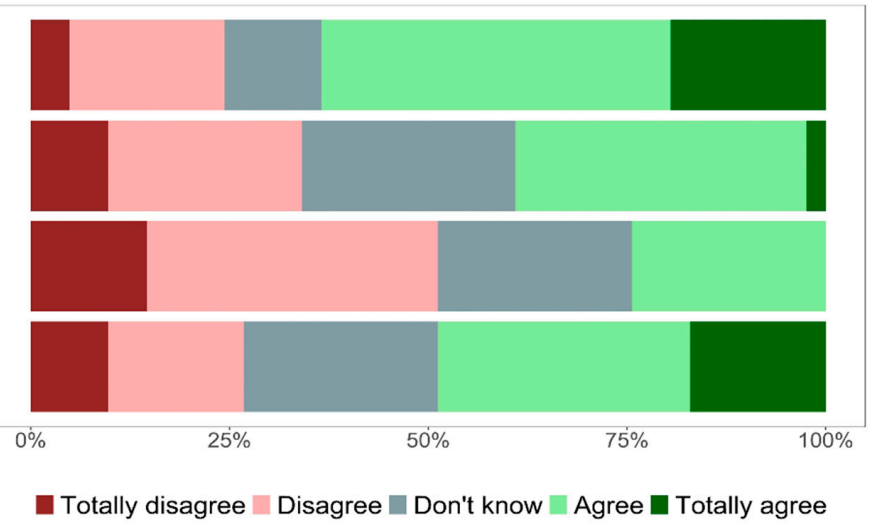

Figure 4. Positions of interviewed people regarding different issues related to the Common Agricultural Policy based on Likert scale responses from the questionnaires $(\mathrm{N}=41)$. Values are expressed as the percentage of responses over the total number of people interviewed.

Alongside these economic, societal, cultural and political factors, technological factors were also identified as drivers of change in traditional livestock management. These drivers acted on local, regional (i.e., decline of drove roads, farming infrastructures, etc.) and international scales (technification and intensification of farms through policies such as the CAP). Regarding the natural drivers, interviewees mentioned those related to the expansion of wild large vertebrates as a result of rewilding processes linked to land abandonment; particularly, the insufficient response of the administration to the increasing attacks on livestock by large carnivores (grey wolf) and strict scavengers (vultures), as well as disease transmission by wild ungulates.

\subsection{Landscape Values Perceived by Interviewees}

We registered different opinions and attitudes amongst stakeholders regarding the landscape changes and values due to abandonment, the persistence of livestock farming and urban growth. Officers perceived shrub expansion as an opportunity $(\mathrm{N}=7 ; 16 \%)$, while rural stakeholders and ecologists perceived it as a threat $(\mathrm{N}=8$ and $\mathrm{N}=4,19 \%$ and $9 \%$, respectively). In CV, stakeholders tended to show polarized attitudes regarding this process. Even so, shrub expansion was perceived more as an opportunity in CV than in SR, where land abandonment was more evident (Figure 5a). Among the opportunities of shrub expansion, stakeholders considered this process would (i) benefit biodiversity, 
(ii) prevent from soil erosion and (iii) provide food for goats and pollinators (Figure $5 b$ ). However, threats were numerically higher; the increase of wildfire risk was the most cited (see below). Some farmers were further concerned about the irreversible process of shrub encroachment and afforestation, leading to pasture loss (Figure 5b).

(a)

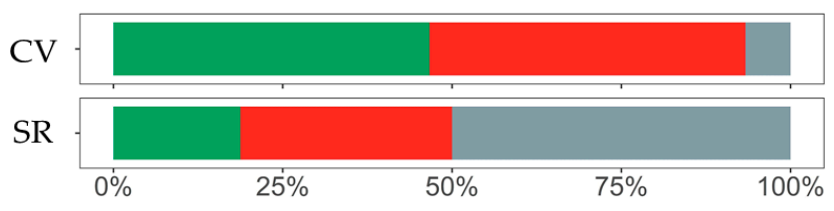

Opportunity $\square$ Threat $\square$ Neither of them

(b)

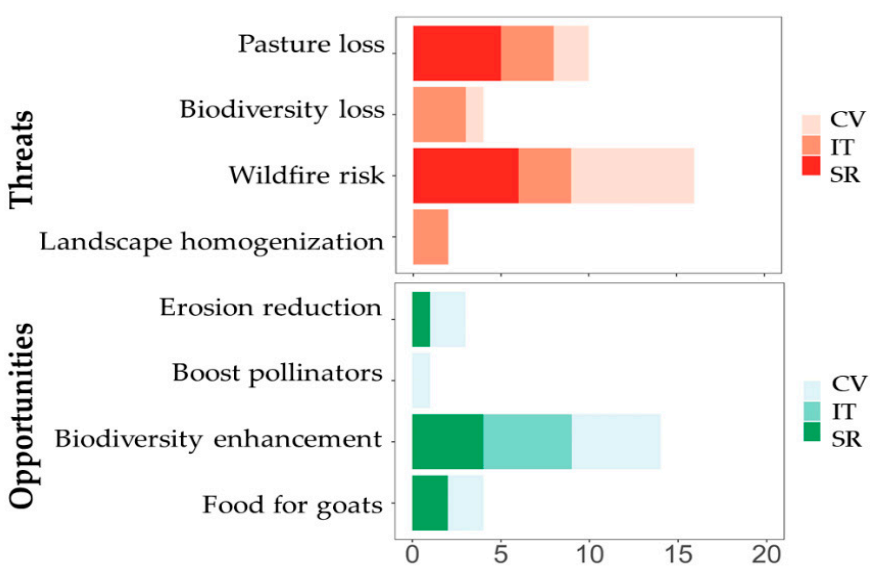

Figure 5. Stakeholder views on shrub expansion in the study areas (a) perceived as threat, opportunity or neither of them, shown as the percentage of responses over the total number of people interviewed within each study area, and (b) consequences of shrub expansion identified as threat or opportunity by interviewees represented by the number of citations. CV: interviewees from Colmenar Viejo and Tres Cantos; SR: interviewees from municipalities of Sierra del Rincón; IT: Interterritorial interviewees.

Focusing on livestock farming, the most pervasive positioning among stakeholders was the positive value given to extensive livestock farming in the territory such as: (i) a driver of employment and economic activity in rural areas $(\mathrm{N}=17 ; 41 \%)$; (ii) the conservation of biocultural heritage comprising the uses and traditions of these systems $(\mathrm{N}=5)$; (iii) the conservation of characteristic species $(\mathrm{N}=29 ; 70 \%)$ : "there are many species of flora and fauna and EU Habitats of Community Interest that depend on these cultural landscapes" (AC); and (iv) its role in wildfire prevention by removing vegetation that fuels wildfires ( $\mathrm{N}=19 ; 46 \%)$ This contrasted with the perception that the role of "fire brigades" could not be played by wild ungulates ( $\mathrm{N}=8 ; 19 \%)$ : "wild herbivorous animals are not going to fulfil the same functions (as livestock), because part of the functions depend on human practices and management of livestock" (AC). Finally, (v) the promotion of locally produced, quality food systems.

Even so, almost half of the interviewees considered that the remaining livestock farms have undergone a process of intensification in recent years, negatively affecting pasture productivity $(\mathrm{N}=19 ; 46 \%)$. Several interviewees further mentioned negative impacts of such practices on different (melliferous) plant and animal (i.e., edaphic invertebrate and amphibian) populations $(\mathrm{N}=6 ; 14 \%)$. In addition, an academic and a livestock farmer warned on the impacts of climate change on grazing areas and stressed that current stocking rates would need to be adapted to pasture productivity. Several stakeholders from different social groups emphasized their concern about the increasing social rejection of livestock farming for its contribution to greenhouse gas emissions ( $\mathrm{N}=10 ; 24 \%)$.

Regarding the loss of primary sector in favor of secondary and tertiary sectors, a majority of actors believed that urban growth in $\mathrm{CV}$ was excessive, that urban growth 
threatened livestock farming and impacted on natural habitats and biodiversity $(\mathrm{N}=17$; 41\%): "Colmenar seems to want to pave the way so that agriculture is not a problem to go on (urban) growing" (Fcv4). In contrast, local administration was favorable to this growth: "I think that nowadays the general urban development plan has not expanded in a way that affects the rural world in such an aggressive way" (ADcv).

There were divergent positions amongst interviewees on the promotion of tourism and recreational activities (tertiary sector): some stakeholders supported the opportunities brought by tourism as an alternative to declining livestock farming. Others argued that these landscapes would not be attractive for tourism without the livestock farming activity that preserves them: "The SR is tourism, there is still some livestock farming, but in 15 years I don't know who wants to go and see a scrubland ... maybe what they wanted to watch were cattle, fields ... the demand for tourism is driving this landscape towards an inertia that is its own suicide". (AC).

\subsection{Landscape Stewardship Desired by Interviewees}

Half of the actors called for more inclusive participatory landscape planning in the medium and long term, bringing together administration, science and society $(\mathrm{N}=22$; $53 \%$ ). The implementation of this planning was demanded as a process of integration at different levels: (i) policy interventions, between different management areas, e.g., rural development (agriculture, forestry, tourism) and biodiversity conservation; (ii) societal: between rural and urban perspectives; and (iii) livestock production: between traditional/conventional management practices and novel approaches. Likewise, there was also a plea for greater coordination between the social actors to achieve a sustainable use of the territory.

Furthermore, social actors requested context-specific solutions, since they perceived that policies were conceived in "offices" far away from rural areas $(\mathrm{N}=17 ; 41 \%)$. "Standard solutions are not valid, because each territory and each type of livestock has its own management" (FRsr). Even actors from the administration recognized the scant flexibility and inefficiency of the administration. Some of the policy interventions most demanded by the interviewees, including farmers, officers and ecologists were (i) the engagement of livestock farmers in programs of fire control through grazing shrublands: (ii) the maintenance of HNV farming; and (iii) helping livestock farmers to carry out environmentally responsible practices $(\mathrm{N}=9 ; 22 \%)$. A drawback highlighted by administration (and recognized by several farmers) to promoting and strengthening local/regional interventions was the lack of cohesion amongst farmers when dealing with administration: "I believe that more unity is also needed in trying to ensure that there are representatives who truly represent the sector" (VTcv). On the other hand, an important part of those context-specific policies should be focused on revitalizing rural areas such as SR. Here, interviewees demanded broadening and improving basic services such as health, education, transport or internet as a crucial step to prevent the emigration of rural population.

Stakeholders further recognized the crucial need for wider societal recognition of the economic, cultural and ecological roles of extensive livestock farming $(\mathrm{N}=16 ; 39 \%)$ : “we would need education and consume local livestock products as the act of managing the territory and paying a fair price for it" (AC). One of the instruments mentioned to recognize the added value of extensive livestock farming was distinctive names such as the Protected Geographical Indication or Protected Designation of Origin. In this vein, several actors, including some farmers, pointed out the relevance of recovering traditional management practices for: (i) increasing landscape sustainability and reducing land impact; (ii) removing intermediaries in product sales; and (iii) fostering local markets (direct sales to local consumers, restaurants, tourists).

\section{Discussion}

Our results show a dual process of progressive abandonment of HNV systems linked to traditional agricultural and livestock farming and an ever-increasing urban growth 
and touristification over the last three decades as the most important driving forces. This is explained by a generalized increase in the secondary and tertiary sectors driven by Madrid city. This pattern takes different paths according to the urban-rural gradient but shares the relegation of the primary sector to the background. Some authors suggest that the incorporation of Spain into the EEC (1986) led to important social, economic and technological effects that catalyzed these processes [42]. Particularly, land use decisions in Europe were strongly influenced by the CAP $[35,43]$. These results agree with previous Pan-European studies, mirroring the shared patterns and trends of landscape change in the European context [6,11,44-46], and particularly in the Iberian Peninsula (Portugal and Spain; $[47,48])$.

Our results show divergent landscape trajectories according to the regional urbanrural gradient in the most densely populated region of Spain (845.2 indiv. $/ \mathrm{km}^{2}$; [49]): despite not being far from Madrid city $(90 \mathrm{~km})$, the more rural areas (SR) are undergoing a steady abandonment of traditional practices since the 1950s, whereas tourism and leisure activities are replacing traditional economies. In contrast, peri-urban areas with a rural history (CV) are facing an explosive urban sprawl, as described in other European areas [2]. Thus, urban society is exerting different pressures according to its needs for: (i) housing close to the workplace (CV); and (ii) leisure activities within distances easily accessed on weekends (SR).

Interviewees agreed with the land cover changes mapped with CORINE in both areas and within the urban-rural gradient. Interviewees also mentioned a more evident abandonment of land uses in areas far away from villages than the ones mapped in our analyses (particularly in SR). This may be due to the increased difficulty of mapping transitional covers corresponding to vegetation successional stages of abandonment, particularly the shrubland expansion $[37,50]$. An alternative explanation is that abandonment of areas away from villages was more intense before 1990. In any case, both mapping analyses and social perceptions seem to draw a good picture of landscape changes and trajectories in the study areas. Furthermore, interviewees could identify the patterns more difficult to capture at local scales with CORINE, thus highlighting the suitability of combining both approaches [10,45].

Stakeholders highlighted EU policies such as the earlier CAP and global food markets as high-impact underlying drivers responsible for the decline of pasture-based livestock farming at broad scales $[35,45]$. However, several interviewees recognized that recent CAP instruments have contributed to halting their abandonment [35,51]. Additionally, more regional or local underlying drivers may also be pushing these HNV systems to abandonment or conversion into urbanized areas. In this vein, interviewees pointed out societal, political and economic drivers such as the lack of generational turnover due to the hard life and low profitability of farms, as previously reported [52]. Local actors further stated the difficulty of becoming a shepherd/farmer due to limited or no access to land, despite fields being abandoned. This paradox was especially the case in SR, where land use for grazing do not compete with urban development. However, there is a social reluctance to offer lands for developing traditional activities to incoming people. This social driver could be regulated by the administration through legislation on land use and land tenure (i.e., regulation of prices and rent supply). On the other hand, the scarce support from administration was also highlighted by rural actors as an important political constraint. This perception produces tensions between rural stakeholders and the administration, leading to a lack of dialogue between the parties. Thus, the promotion of participatory governance processes is essential to unblock the situation [53-55].

Addressing and understanding people's perceptions and values with respect to landscape changes and trajectories is of great value in reflecting on and outlining modern policymaking $[14,19,56,57]$. Our results show how actors in the territory perceived and valued the processes of landscape change in a different manner. For people in rural areas, land abandonment means the permanent loss of pastures, the loss of biocultural heritage and their linkage with the territory [58]. For ecologists, land abandonment favors 
landscape homogenization [52]. Moreover, woody encroachment increases the risk of wildfire, which is especially worrying in Mediterranean ecosystems due to summer high temperatures and dry conditions in conjunction with global warming [59]. Some ecologists also emphasized that several habitats included in the EU Habitats Directive (92/43/EEC), depend on livestock use, so that its abandonment jeopardizes their conservation. Others argue that land abandonment prevents soil erosion, though recent studies have shown that abandonment of extensive livestock systems in central Spain decreases soil fertility, carbon sequestration [60] and microbial activity [61]. Some authors argue that land abandonment offers opportunities for biodiversity conservation, such as forest bird species [62] and large mammals $[63,64]$. Nevertheless, rewilding brings new threats and challenges for farmers, administration and society on how to coexist with wild fauna $[65,66]$ which was underlined by stakeholders. Summarizing, we agree that the debate on agricultural abandonment should focus more on target-nuanced, context-dependent policy and management strategies [67]. What is more, to reach negotiated solutions in which multifunctional landscapes are preserved, participatory processes that encompass the diverse values and views of the stakeholders involved are urgently needed and demanded [68-70].The mounting urban sprawl in CV over the last decades is widely considered a threat for traditional livestock farming and cultural identity, causing air quality degradation (due to the massive use of private vehicles) and overcrowded use of the environment [2]. In general, interviewees showed divergent feelings and positions between desired landscape trajectories and those actually experienced, both in more rural areas and new urbanized areas. This poses the pressing need for building participatory governance models that incorporate people's values for landscape planning [71,72].

Several stakeholders considered that, by promoting extensive livestock farming, cultural landscapes can be preserved alongside the production of quality food products from farming systems that adhere to animal-welfare conditions not seen in the increasing industrial farming. Furthermore, by fostering local markets and initiatives such as the $\mathrm{Km} 0$ (eating food locally produced) or 'Farm to fork' (EU strategy that promotes fairer, healthier and environmentally-friendly food systems) [73] and valuing local products, we can contribute to preserving extensive livestock systems [74]. In addition, the disruptions caused by COVID-19 in several market supplies at global and regional scales highlight the need of strengthening local markets [71]. However, behind market regulations, the reduction in meat consumption is a pressing need worldwide, due to its major, negative consequences for land and water use and environmental change [75]. Extensive livestock farming certainly emerges as an alternative to industrial livestock production for its social, environmental and economic contribution in rural areas [76,77], where it leads to the maintenance of multifunctional landscapes [78]. Even more, by strengthening pasture-based livestock systems from the economic, ecological and technological dimensions, we can contribute to the increasing societal and scientific demand towards agroecological transitions of agricultural systems [79].

Thinking, valuing and planning the countryside is done mainly by urbanites while rural development is mainly focused upon the urban needs [1]. This was a common view among interviewees of the more rural areas (SR). To reverse this situation several actors advocated for science-based, stakeholder-inclusive and participatory landscape planning and co-management, leading to more context-specific, regionalized policymaking $[11,80]$. "It seems as if the administration and the society do not know whether the use of cultural landscapes should be for production, conservation or tourism" (AC). Thus, it is crucial to overcome sectoral approaches from different administrations (e.g., farming and rural development, nature conservation, tourism administration, and local, regional, national administration, etc.) which, to date, have promoted even opposing policy interventions regarding the countryside and rural development. The transition to more participatory and democratic governance models, in which different stakeholders get involved in landscape stewardship, was growing among social actors. Some of them went further and called for multifunctional landscape planning that integrates social, ecological, economic and 
cultural demands [56]. Multifunctional landscapes must ensure both ecological functions and ecosystem services [81]. They should be rooted in the idea of coexisting land uses based on traditional practices (agriculture, livestock, forestry), conservation aims and tourism activities, even urban growth, within sustainable planning management frameworks codesigned by stakeholders [82].

To conclude, our results show a shared pattern of landscape change with other European regions. This pattern is characterized by the progressive abandonment of traditional farming practices and their replacement by tourism in areas far from Madrid city (SR). In contrast, extensive livestock farming coexists with the growing urban sprawl in areas close to Madrid city (CV). If our aim as a society is to preserve the HNV landscapes, we must bring the needs of the rural stakeholders that support them to the forefront while we balance the impact of the urban population needs. Our results show how social actors do not feel satisfied with the current landscape trends. Stakeholders further advocate for participatory stakeholder-inclusive governance frameworks in search of more sustainable rural planning that lead to the coexistence of traditional practices with the increasing secondary and tertiary sectors. Finally, the identification of proximate and underlying drivers from interviewee discourses have proven to be valuable for analyzing landscape trajectories.

Supplementary Materials: The following are available online at https://www.mdpi.com/article/10 .3390 /agriculture11111107/s1, Information about the reclassification process. Table S1: The standard CORINE Land Cover nomenclature for the 3 level 1 classes identified in our study. Tables S2-S5: Description of the original CLC classes that make up the new categories for SR and CV in 1990 and 2018. Table S6: Land uses and covers at village-level based on Corine Land Cover Project (CLC 1990 and 2018).

Author Contributions: Conceptualization, P.A. and Z.I.-G.; methodology, P.A., F.J.M.-G. and Z.I.-G.; software, F.J.M.-G. and Z.I.-G.; validation, P.A.; investigation; P.A., F.J.M.-G., Z.I.-G.; writing—original draft preparation, P.A.; writing—review and editing, F.J.M.-G. and Z.I.-G. All authors have read and agreed to the published version of the manuscript.

Funding: This research received no external funding.

Institutional Review Board Statement: Ethical review and approval were waived for this study because the information used was completely anonymous; no personal information was compiled but we requested an informed consent of all interviewees before starting the interview (see "Interview design and analyses" section).

Informed Consent Statement: Informed consent was obtained from all subjects involved in the study.

Data Availability Statement: Not applicable.

Acknowledgments: Authors would like to thank three anonymous reviewers for contributions that improved the manuscript. Authors would especially like to thank all participants engaged in this study, and M. García-Llorente and D. López for contributing to the design of the interview / questionnaire. F.J.M.-G. hold a grant from Comunidad de Madrid-EU Social Fund (PEJD-2019PRE/AMB-16775). Authors would also like to thank the REMEDINAL TE project (P2018/EMT-4338; Madrid Regional Government and EU Social Fund).

Conflicts of Interest: The authors declare no conflict of interest.

\section{References}

1. Antrop, M. Landscape Change and the Urbanization Process in Europe. Landsc. Urban Plan. 2004, 67, 9-26. [CrossRef]

2. Shaw, B.J.; van Vliet, J.; Verburg, P.H. The Peri-Urbanization of Europe: A Systematic Review of a Multifaceted Process. Landsc. Urban Plan. 2020, 196, 103733. [CrossRef]

3. MacDonald, D.; Crabtree, J.R.; Wiesinger, G.; Dax, T.; Stamou, N.; Fleury, P.; Gutierrez Lazpita, J.; Gibon, A. Agricultural Abandonment in Mountain Areas of Europe: Environmental Consequences and Policy Response. J. Environ. Manag. 2000, 59, 47-69. [CrossRef]

4. Van der Sluis, T.; Pedroli, B.; Frederiksen, P.; Kristensen, S.B.P.; Busck, A.G.; Pavlis, V.; Cosor, G.L. The Impact of European Landscape Transitions on the Provision of Landscape Services: An Explorative Study Using Six Cases of Rural Land Change. Landsc. Ecol. 2019, 34, 307-323. [CrossRef] 
5. Montserrat, P. La fertilidad del paisaje. In La Cultura que Hace el Paisaje; La Fertilidad de la Tierra Ediciones: Navarra, Spain, 2009.

6. Plieninger, T.; Draux, H.; Fagerholm, N.; Bieling, C.; Bürgi, M.; Kizos, T.; Kuemmerle, T.; Primdahl, J.; Verburg, P.H. The Driving Forces of Landscape Change in Europe: A Systematic Review of the Evidence. Land Use Policy 2016, 57, 204-214. [CrossRef]

7. Oppermann, R.; Beaufoy, G.; Jones, G. High Nature Value Farming in Europe; Verlag Regionalkultur: Ubstadt-Weiher, Germany, 2012.

8. Lomba, A.; Guerra, C.; Alonso, J.; Honrado, J.P.; Jongman, R.; McCracken, D. Mapping and Monitoring High Nature Value Farmlands: Challenges in European Landscapes. J. Environ. Manag. 2014, 143, 140-150. [CrossRef]

9. Acebes, P.; Pereira, D.; Oñate, J.J. Towards the Identification and Assessment of HNV Dehesas: A Meso-Scale Approach. Agrofor. Syst. 2016, 90, 7-22. [CrossRef]

10. García-Martín, M.; Quintas-Soriano, C.; Torralba, M.; Wolpert, F.; Plieninger, T. Landscape Change in Europe. In Sustainable Land Management in a European Context; Springer International Publishing: Cham, Switzerland, 2021; pp. 17-37. ISBN 9783030508418.

11. Kuemmerle, T.; Levers, C.; Erb, K.; Estel, S.; Jepsen, M.R.; Müller, D.; Plutzar, C.; Stürck, J.; Verkerk, P.J.; Verburg, P.H.; et al. Hotspots of Land Use Change in Europe. Environ. Res. Lett. 2016, 11, 064020. [CrossRef]

12. Verburg, P.H.; Kok, K.; Pontius, R.G.; Veldkamp, A. Modeling land-use and land-cover change. In Land-Use and Land-Cover Change; Springer: Dordrecht, The Netherlands, 2006; pp. 117-135.

13. Klijn, J.A. Driving Forces behind Landscape Transformation in Europe, from a Conceptual Approach to Policy Options. In The New Dimensions in European Landscapes; Jongman, R.H.G., Ed.; Springer: Wageningen, The Netherlands, $2004 ;$ pp. $210-218$.

14. Garcia-Martin, M.; Fagerholm, N.; Bieling, C.; Gounaridis, D.; Kizos, T.; Printsmann, A.; Müller, M.; Lieskovský, J.; Plieninger, T. Participatory Mapping of Landscape Values in a Pan-European Perspective. Landsc. Ecol. 2017, 32, 2133-2150. [CrossRef]

15. Munthali, M.G.; Davis, N.; Adeola, A.M.; Botai, J.O.; Kamwi, J.M.; Chisale, H.L.W.; Orimoogunje, O.O.I. Local Perception of Drivers of Land-Use and Land-Cover Change Dynamics across Dedza District, Central Malawi Region. Sustainability 2019, 11, 832. [CrossRef]

16. Gomes, L.C.; Bianchi, F.J.J.A.; Cardoso, I.M.; Schulte, R.P.O.; Arts, B.J.M.; Fernandes Filho, E.I. Land Use and Land Cover Scenarios: An Interdisciplinary Approach Integrating Local Conditions and the Global Shared Socioeconomic Pathways. Land Use Policy 2020, 97, 104723. [CrossRef]

17. Brown, J.; Mitchell, B. The Stewardship Approach and Its Relevance for Protected Landscapes. Georg. Wright Forum 2000, $17,70-79$.

18. Gundersen, V.; Mäkinen, K. Aldo Leopold and Stewardship: Lessons for Forest Planning and Management in the Nordic Countries? Nor. Geogr. Tidsskr. 2009, 63, 225-232. [CrossRef]

19. Chan, K.M.A.; Balvanera, P.; Benessaiah, K.; Chapman, M.; Díaz, S.; Gómez-Baggethun, E.; Gould, R.; Hannahs, N.; Jax, K.; Klain, S.; et al. Opinion: Why Protect Nature? Rethinking Values and the Environment. Proc. Natl. Acad. Sci. USA 2016, 113, 1462-1465. [CrossRef]

20. Arias-Arévalo, P.; Martín-López, B.; Gómez-Baggethun, E. Exploring Intrinsic, Instrumental, and Relational Values for Sustainable Management of Social-Ecological Systems. Ecol. Soc. 2017, 22, 43. [CrossRef]

21. Fischer, J.; Riechers, M.; Loos, J.; Martin-Lopez, B.; Temperton, V.M. Making the UN Decade on Ecosystem Restoration a Social-Ecological Endeavour. Trends Ecol. Evol. 2021, 36, 20-28. [CrossRef]

22. Kizos, T.; Verburg, P.H.; Bürgi, M.; Gounaridis, D.; Plieninger, T.; Bieling, C.; Balatsos, T. From Concepts to Practice: Combining Different Approaches to Understand Drivers of Landscape Change. Ecol. Soc. 2018, 23. [CrossRef]

23. Owen, R.; Macnaghten, P.; Stilgoe, J. Responsible Research and Innovation: From Science in Society to Science for Society, with Society. Sci. Public Policy 2012, 39, 751-760. [CrossRef]

24. Vogel, I. Review of the Use of 'Theory of Change' in International Development; 2012.

25. Enqvist, J.P.; West, S.; Masterson, V.A.; Haider, L.J.; Svedin, U.; Tengö, M. Stewardship as a Boundary Object for Sustainability Research: Linking Care, Knowledge and Agency. Landsc. Urban Plan. 2018, 179, 17-37. [CrossRef]

26. Folke, C.; Hahn, T.; Olsson, P.; Norberg, J. Adaptative governance of social-ecological systems. Annu. Rev. Environ. Resour. 2005, 30, 441-473. [CrossRef]

27. O'Farrell, P.J.; Anderson, P.M.L. Sustainable Multifunctional Landscapes: A Review to Implementation. Curr. Opin. Environ. Sustain. 2010, 2, 59-65. [CrossRef]

28. Cocca, G.; Sturaro, E.; Gallo, L.; Ramanzin, M. Is the Abandonment of Traditional Livestock Farming Systems the Main Driver of Mountain Landscape Change in Alpine Areas? Land Use Policy 2012, 29, 878-886. [CrossRef]

29. Delattre, L.; Debolini, M.; Paoli, J.C.; Napoleone, C.; Moulery, M.; Leonelli, L.; Santucci, P. Understanding the Relationships between Extensive Livestock Systems, Land-Cover Changes, and CAP Support in Less-Favored Mediterranean Areas. Land 2020, 9, 518. [CrossRef]

30. Zscheischler, J.; Rogga, S.; Busse, M. The Adoption and Implementation of Transdisciplinary Research in the Field of Land-Use Science-A Comparative Case Study. Sustainability 2017, 9, 1926. [CrossRef]

31. IECM (Instituto de Estadística de La Comunidad de Madrid). 2020. Available online: https://www.madrid.org/iestadis/ (accessed on 21 December 2020).

32. Hewitt, R.; Escobar, F. The Territorial Dynamics of Fast-Growing Regions: Unsustainable Land Use Change and Future Policy Challenges in Madrid, Spain. Appl. Geogr. 2011, 31, 650-667. [CrossRef]

33. Gallardo, M.; Martínez-Vega, J. Three Decades of Land-Use Changes in the Region of Madrid and How They Relate to Territorial Planning. Eur. Plan. Stud. 2016, 24, 1016-1033. [CrossRef] 
34. Johnson, R.B.; Onwuegbuzie, A.J. Mixed Methods Research: A Research Paradigm Whose Time Has Come. Educ. Res. 2004, 33, 14-26. [CrossRef]

35. Pe'er, G.; Bonn, A.; Bruelheide, H.; Dieker, P.; Eisenhauer, N.; Feindt, P.H.; Hagedorn, G.; Hansjürgens, B.; Herzon, I.; Lomba, A.; et al. Action Needed for the EU Common Agricultural Policy to Address Sustainability Challenges. People Nat. 2020, 2, 305-316. [CrossRef]

36. Copernicus CORINE Land Cover. Available online: https://land.copernicus.eu/pan-european/corine-land-cover2021 (accessed on 12 October 2021).

37. García-Álvarez, D.; Camacho Olmedo, M.T. Changes in the Methodology Used in the Production of the Spanish CORINE: Uncertainty Analysis of the New Maps. Int. J. Appl. Earth Obs. Geoinf. 2017, 63, 55-67. [CrossRef]

38. Soukup, T.; Büttner, G.; Feranec, J.; Hazeu, G.; Jaffrain, G.; Jindrova, M.; Kopecky, M.; Orlitova, E. CORINE Land Cover 2006-2012 changes: Analysis and assessment. In European Landscape Dynamics; CRC Press: Boca Raton, FL, USA, 2016; pp. 141-146, ISBN 131537286X.

39. Young, J.C.; Rose, D.C.; Mumby, H.S.; Benitez-Capistros, F.; Derrick, C.J.; Finch, T.; Garcia, C.; Home, C.; Marwaha, E.; Morgans, C.; et al. A Methodological Guide to Using and Reporting on Interviews in Conservation Science Research. Methods Ecol. Evol. 2018, 9, 10-19. [CrossRef]

40. Lune, H.; Berg, B.L. Qualitative Research Methods for the Social Sciences; Pearson: Harlow, UK, 2017.

41. Wickham, H. Ggplot2: Elegant Graphics for Data Analysis; Springer: New York, NY, USA, 2016; Available online: https://ggplot2 .tidyverse.org (accessed on 19 May 2021).

42. Corbelle-Rico, E.; Butsic, V.; Enríquez-García, M.J.; Radeloff, V.C. Technology or Policy? Drivers of Land Cover Change in Northwestern Spain before and after the Accession to European Economic Community. Land Use Policy 2015, 45, 18-25. [CrossRef]

43. Lomba, A.; Moreira, F.; Klimek, S.; Jongman, R.H.; Sullivan, C.; Moran, J.; Poux, X.; Honrado, J.P.; Pinto-Correia, T.; Plieninger, T.; et al. Back to the Future: Rethinking Socioecological Systems Underlying High Nature Value Farmlands. Front. Ecol. Environ. 2020, 18, 36-42. [CrossRef]

44. Estel, S.; Kuemmerle, T.; Alcántara, C.; Levers, C.; Prishchepov, A.; Hostert, P. Mapping Farmland Abandonment and Recultivation across Europe Using MODIS NDVI Time Series. Remote Sens. Environ. 2015, 163, 312-325. [CrossRef]

45. Bürgi, M.; Bieling, C.; von Hackwitz, K.; Kizos, T.; Lieskovský, J.; Martín, M.G.; McCarthy, S.; Müller, M.; Palang, H.; Plieninger, T.; et al. Processes and Driving Forces in Changing Cultural Landscapes across Europe. Landsc. Ecol. 2017, 32, 2097-2112. [CrossRef]

46. Fuchs, R.; Herold, M.; Verburg, P.H.; Clevers, J.G.P.W.; Eberle, J. Gross Changes in Reconstructions of Historic Land Cover/Use for Europe between 1900 and 2010. Glob. Chang. Biol. 2015, 21, 299-313. [CrossRef] [PubMed]

47. Fernández-Nogueira, D.; Corbelle-Rico, E. Land Use Changes in Iberian Peninsula 1990-2012. Land 2018, 7, 99. [CrossRef]

48. Van der Zanden, E.H.; Carvalho-Ribeiro, S.M.; Verburg, P.H. Abandonment Landscapes: User Attitudes, Alternative Futures and Land Management in Castro Laboreiro, Portugal. Reg. Environ. Chang. 2018, 18, 1509-1520. [CrossRef] [PubMed]

49. INE Instituto Nacional de Estadística. 2020. Available online: https:/ / www.ine.es / (accessed on 3 November 2020).

50. Martínez-Fernández, J.; Ruiz-Benito, P.; Bonet, A.; Gómez, C. Methodological Variations in the Production of CORINE Land Cover and Consequences for Long-Term Land Cover Change Studies. The Case of Spain. Int. J. Remote. Sens. 2019, 40, 8914-8932. [CrossRef]

51. Lefebvre, M.; Espinosa, M.; Gomez y Paloma, S. The Influence of the Common Agricultural Policy on Agricultural Landscapes. JS a. P. Report; European Commission, Joint Research Center: Luxembourg, 2012; p. 83.

52. Bernués, A.; Ruiz, R.; Olaizola, A.; Villalba, D.; Casasús, I. Sustainability of Pasture-Based Livestock Farming Systems in the European Mediterranean Context: Synergies and Trade-Offs. Livest. Sci. 2011, 139, 44-57. [CrossRef]

53. Fischer, F. Participatory Governance: From Theory to Practice. In The Oxford Handbook of Governance; Oxford University Press: Oxford, UK, 2012. [CrossRef]

54. Newig, J.; Fritsch, O. Environmental Governance: Participatory, Multi-Level-And Effective? Environ. Policy Gov. 2009, 19, 197-214. [CrossRef]

55. Bermejo-Asensio, L.A.; Lobillo-Eguíbar, J.; Molina-Afonso, C. Aportes Del DRP (Diagnóstico Rural Participativo) a Las Metodologías Participativas y Aplicación a La Gestión de Los Recursos Naturales En La Gomera. Práxis Particip. Desde Medio Rural. 2003, 6, 71.

56. Verkerk, P.J.; Lindner, M.; Pérez-Soba, M.; Paterson, J.S.; Helming, J.; Verburg, P.H.; Kuemmerle, T.; Lotze-Campen, H.; Moiseyev, A.; Müller, D.; et al. Identifying Pathways to Visions of Future Land Use in Europe. Reg. Environ. Chang. 2018, 18, 817-830. [CrossRef]

57. Rolo, V.; Hartel, T.; Aviron, S.; Berg, S.; Crous-Duran, J.; Franca, A.; Mirck, J.; Palma, J.H.N.; Pantera, A.; Paulo, J.A.; et al. Challenges and Innovations for Improving the Sustainability of European Agroforestry Systems of High Nature and Cultural Value: Stakeholder Perspectives. Sustain. Sci. 2020, 15, 1301-1315. [CrossRef]

58. Quintas-Soriano, C.; Castro, A.J.; Castro, H.; García-Llorente, M. Impacts of Land Use Change on Ecosystem Services and Implications for Human Well-Being in Spanish Drylands. Land Use Policy 2016, 54, 534-548. [CrossRef]

59. Pausas, J.G.; Fernández-Muñoz, S. Fire Regime Changes in the Western Mediterranean Basin: From Fuel-Limited to DroughtDriven Fire Regime. Clim. Chang. 2012, 110, 215-226. [CrossRef] 
60. Peco, B.; Navarro, E.; Carmona, C.P.; Medina, N.G.; Marques, M.J. Effects of Grazing Abandonment on Soil Multifunctionality: The Role of Plant Functional Traits. Agric. Ecosyst. Environ. 2017, 249, 215-225. [CrossRef]

61. Oggioni, S.D.; Ochoa-Hueso, R.; Peco, B. Livestock Grazing Abandonment Reduces Soil Microbial Activity and Carbon Storage in a Mediterranean Dehesa. Appl. Soil Ecol. 2020, 153. [CrossRef]

62. Sirami, C.; Brotons, L.; Burfield, I.; Fonderflick, J.; Martin, J.L. Is Land Abandonment Having an Impact on Biodiversity? A Meta-Analytical Approach to Bird Distribution Changes in the North-Western Mediterranean. Biol. Conserv. 2008, 141, 450-459. [CrossRef]

63. Carpio, A.J.; Apollonio, M.; Acevedo, P. Wild Ungulate Overabundance in Europe: Contexts, Causes, Monitoring and Management Recommendations. Mammal Rev. 2021, 51, 95-108. [CrossRef]

64. Cimatti, M.; Ranc, N.; Benítez-López, A.; Maiorano, L.; Boitani, L.; Cagnacci, F.; Čengić, M.; Ciucci, P.; Huijbregts, M.A.J.; Krofel, M.; et al. Large Carnivore Expansion in Europe Is Associated with Human Population Density and Land Cover Changes. Divers. Distrib. 2021, 27, 602-617. [CrossRef]

65. Carter, N.H.; Linnell, J.D.C. Co-Adaptation Is Key to Coexisting with Large Carnivores. Trends Ecol. Evol. 2016, 31, 575-578. [CrossRef]

66. Pozo, R.A.; Cusack, J.J.; Acebes, P.; Malo, J.E.; Traba, J.; Iranzo, E.C.; Morris-Trainor, Z.; Minderman, J.; Bunnefeld, N.; RadicSchilling, S.; et al. Reconciling Livestock Production and Wild Herbivore Conservation: Challenges and Opportunities. Trends Ecol. Evol. 2021, 36, 750-761. [CrossRef] [PubMed]

67. Van der Zanden, E.H.; Verburg, P.H.; Schulp, C.J.E.; Verkerk, P.J. Trade-Offs of European Agricultural Abandonment. Land Use Policy 2017, 62, 290-301. [CrossRef]

68. Sinclair, K.; Curtis, A.; Freeman, P. Biosecurity in Multifunctional Landscapes: Challenges for Approaches Based on the Concept of 'Shared Responsibility'. Prev. Vet. Med. 2020, 178, 104682. [CrossRef] [PubMed]

69. Cockburn, J.; Cundill, G.; Shackleton, S.; Rouget, M.; Zwinkels, M.; Cornelius, S.A.; Metcalfe, L.; van den Broeck, D. Collaborative Stewardship in Multifunctional Landscapes: Toward Relational, Pluralistic Approaches. Ecol. Soc. 2019, 24. [CrossRef]

70. Vila-Subirós, J.; Rodríguez-Carreras, R.; Varga, D.; Ribas, A.; Úbeda, X.; Asperó, F.; Llausàs, A.; Outeiro, L. Stakeholder Perceptions of Landscape Changes in the Mediterranean Mountains of the North-Eastern Iberian Peninsula. Land Degrad. Dev. 2016, 27, 1354-1365. [CrossRef]

71. Esgalhado, C.; Guimarães, M.H.; Lardon, S.; Debolini, M.; Balzan, M.V.; Gennai-Schott, S.C.; Simón Rojo, M.; Mekki, I.; Bouchemal, S. Mediterranean Land System Dynamics and Their Underlying Drivers: Stakeholder Perception from Multiple Case Studies. Landsc. Urban Plan. 2021, 213, 104134. [CrossRef]

72. Herrera-Calvo, P.M.; García-Fernández, J. Dialogue, Participation and Social Innovation Initiatives for Improving Territorial Governance in Rural Environments. Ciudades 2021, 45-64. [CrossRef]

73. Commission, E. A Farm to Fork Strategy for Fair, Healthy and Environmentally-Friendly Food System. In Proceedings of the Communication from the Commision to the European Parliament, the Council, the European Economic and Social Comittee and the Comitte of the Regions, Brussels, Belgium, 20 May 2020.

74. Herrera-Calvo, P.M.; Majadas-Andray, J.; Esteban, A.; Ramírez, N.; Rico, L. La Ganadería Extensiva, Una Actividad Clave Para Nuestra Alimentación; Fundación Entretantos: Valladolid, Spain, 2018.

75. Godfray, H.C.J.; Aveyard, P.; Garnett, T.; Hall, J.W.; Key, T.J.; Lorimer, J.; Pierrehumbert, R.T.; Scarborough, P.; Springmann, M.; Jebb, S.A. Meat Consumption, Health, and the Environment. Science 2018, 361. [CrossRef]

76. Manzano-Baena, P.; Salguero-Herrera, C. Mobile Pastoralism in the Mediterranean: Arguments and Evidence for Policy Reform and to Combat Climate Change. Available online: http://medconsortium.org/wp-content/uploads/2017/12/ MobilePastoralismMotherDocument_December2017_ForWeb.pdf (accessed on 30 September 2021).

77. Manzano, P.; Burgas, D.; Cadahía, L.; Eronen, J.T.; Fernández-Llamazares, Á.; Bencherif, S.; Holand, Ø.; Seitsonen, O.; Byambaa, B.; Fortelius, M.; et al. Toward a Holistic Understanding of Pastoralism. One Earth 2021, 4, 651-665. [CrossRef]

78. Bruley, E.; Locatelli, B.; Lavorel, S. Nature's Contributions to People: Coproducing Quality of Life from Multifunctional Landscapes. Ecol. Soc. 2021, 26, 12. [CrossRef]

79. Ollivier, G.; Magda, D.; Mazé, A.; Plumecocq, G.; Lamine, C. Agroecological Transitions: What Can Sustainability Transition Frameworks Teach Us? An Ontological and Empirical Analysis. Ecol. Soc. 2018, 23. [CrossRef]

80. Fagerholm, N.; Eilola, S.; Kisanga, D.; Arki, V.; Käyhkö, N. Place-Based Landscape Services and Potential of Participatory Spatial Planning in Multifunctional Rural Landscapes in Southern Highlands, Tanzania. Landsc. Ecol. 2019, 34, 1769-1787. [CrossRef]

81. Holt, A.R.; Alix, A.; Thompson, A.; Maltby, L. Food Production, Ecosystem Services and Biodiversity: We Can't Have It All Everywhere. Sci. Total. Environ. 2016, 573, 1422-1429. [CrossRef]

82. Lavorel, S.; Grigulis, K.; Leitinger, G.; Kohler, M.; Schirpke, U.; Tappeiner, U. Historical Trajectories in Land Use Pattern and Grassland Ecosystem Services in Two European Alpine Landscapes. Reg. Environ. Chang. 2017, 17, 2251-2264. [CrossRef] 